Cite this: Phys. Chem. Chem. Phys., 2014, 16, 2831

Received 31st October 2013,

Accepted 16th December 2013

DOI: $10.1039 / c 3 c p 54585 g$

www.rsc.org/pccp

\section{Towards a thermally regenerative all-copper redox flow battery $\dagger$}

\author{
Pekka Peljo, ${ }^{\text {ab }}$ David Lloyd, ${ }^{\text {a }}$ Nguyet Doan, ${ }^{a}$ Marko Majaneva ${ }^{a}$ and Kyösti Kontturi ${ }^{a}$
}

An all-copper redox flow battery based on strong complexation of $\mathrm{Cu}^{+}$with acetonitrile is demonstrated, exhibiting reasonable battery performance. More interestingly, the battery can be charged by heat sources of $100{ }^{\circ} \mathrm{C}$, by distilling off the acetonitrile. This destabilizes the $\mathrm{Cu}^{+}$complex, leading to recovery of the starting materials.

The environmental concerns over the current use of fossil fuels direct us to search for alternative energy sources and to improve the energy efficiency of existing processes. One abundant and almost untapped source of energy is the heat produced in many industrial processes, power plants, ${ }^{1}$ simple solar collectors ${ }^{2}$ or geothermal sources. ${ }^{3}$ In this communication we describe a method to convert heat into electrical energy based on the strong complexation of $\mathrm{Cu}^{+}$by acetonitrile (ACN). This concept was patented some thirty years ago, ${ }^{4}$ but does not appear to have undergone any further development, nor has it ever been reported in the scientific literature.

It is well known since 1923 that copper(I) tetrakisacetonitrile salts are easily prepared by comproportionation of $\mathrm{Cu}$ and $\mathrm{Cu}^{2+}$ in the presence of acetonitrile, forming $\left[\mathrm{Cu}(\mathrm{ACN})_{4}\right]^{+}$, as shown in reaction (1). ${ }^{5,6}$ Recently this methodology has also been used for synthesis of tetrakisacetonitrile copper complex based ionic liquids. ${ }^{7}$ Upon distillation of the $\mathrm{Cu}(\mathrm{I})$ solution the process can be reversed as the stabilizing acetonitrile is removed from the solution, and $\mathrm{Cu}(\mathrm{I})$ undergoes disproportionation. ${ }^{5}$ This principle was utilized in copper leaching by Parker et al. in the 1980s: $\mathrm{CuSO}_{4}$-solutions containing $6 \mathrm{M}$ of acetonitrile were used for leaching of segregated copper from roasted copper sulfide concentrates and ores. ${ }^{8}$ Selective leaching of copper was

\footnotetext{
${ }^{a}$ Department of Chemistry, Aalto University, B.O. Box 16100, 00076 Aalto, Finland. E-mail: david.lloyd@aalto.fi

${ }^{b}$ Laboratoire d'Electrochimie Physique et Analytique, Ecole Polytechnique Fédérale de Lausanne (EPFL), Station 6, 1015 Lausanne, Switzerland

$\dagger$ Electronic supplementary information (ESI) available: Design of the miniature redox flow battery, details of calculations of theoretical capacitance, coulombic and energy efficiencies, examples of charging and discharging cycles, solubility of $\mathrm{CuSO}_{4}$ in water-acetonitrile mixtures. See DOI: $10.1039 / \mathrm{c} 3 \mathrm{cp} 54585 \mathrm{~g}$
}

achieved with careful control of $\mathrm{pH}$, and copper could be recovered as microparticles by distilling off the acetonitrile.

$$
\mathrm{Cu}+\mathrm{Cu}^{2+}+8 \mathrm{ACN} \rightarrow 2\left[\mathrm{Cu}(\mathrm{ACN})_{4}\right]^{+}
$$

In parallel, copper(I) complexes with acetonitrile were utilized in a redox battery: two half-cells separated by an anion exchange membrane with a copper electrode immersed in lithium perchlorate in acetonitrile on one side and a graphite electrode in contact with $\mathrm{Cu}\left(\mathrm{ClO}_{4}\right)_{2}$ in acetonitrile on the other side. ${ }^{9}$ The cell exhibited good cycling stability and coulombic efficiency, with a cell potential of $1.35 \mathrm{~V} .{ }^{9}$ In this paper we combine these two approaches to introduce a thermally regenerable all-copper battery. The system shown in this publication is based on $6 \mathrm{M}$ acetonitrile solutions to allow reasonably high solubility of $\mathrm{CuSO}_{4}$. The other obvious approach would have been to use pure acetonitrile with $\mathrm{Cu}\left(\mathrm{ClO}_{4}\right)_{2}$ to achieve a higher cell potential. However, this approach was abandoned after two small explosions during comproportionation or thermal regeneration steps with perchlorates. The graphical abstract describes the long-term aim of this study, and the working principles are demonstrated in this communication.

In principle the system is a redox flow battery (RFB) with solid copper on the anode side. RFBs are an emerging energy storage technology that converts and stores electrical energy as chemical energy and releases it in a controlled fashion when required, helping to balance power generation and consumption. ${ }^{10,11}$ This is necessary for the effective large-scale deployment of intermittent renewable energy sources, such as wind and solar power. ${ }^{10,11}$

An economical method to convert low grade heat into electricity would be very beneficial. Systems to convert heat into electricity are not novel, but most reported methods require significantly higher temperatures $\left(>200{ }^{\circ} \mathrm{C}\right)$ than the method described in this communication. ${ }^{12,13}$ Since the conversion process proceeds through an intermediate chemical step, energy can readily stored and utilized on demand. 


\section{Experimental}

All chemicals were used as received. Aqueous solutions were prepared with ultrapure water (Millipore Milli-Q, specific resistivity $18.2 \mathrm{M} \Omega \mathrm{cm}$ ). Acetonitrile (ACN, >99.5\%) and $\mathrm{CuSO}_{4} \cdot 5 \mathrm{H}_{2} \mathrm{O}$ (99\%) were purchased from Merck. Copper was obtained from electric wires and copper powder from JT Baker. Fumasep FAB anion exchange membrane (Fumatec) was exchanged into the sulphate form by soaking it in $0.5 \mathrm{M} \mathrm{H}_{2} \mathrm{SO}_{4}$ for one day. Nafion N115 cation exchange membrane (Ion Power Inc.) was pretreated as described earlier. ${ }^{14}$

Electrochemical measurements were done in a thermostated cell. The working electrode was a $5 \mathrm{~mm}$ platinum disc with a Teflon sheath (Pine Research Instrumentation) polished by the normal procedure. ${ }^{15}$ A copper wire was used as a reference and Pt gauze as the counter electrode. The temperature of the system was monitored using a k-type thermocouple. Electrochemical measurements were performed using a Solartron 1286 potentiostat as reported earlier. ${ }^{16}$

The simple miniature redox flow battery described earlier ${ }^{16}$ was used to study the cycling behaviour of the cell (see $\operatorname{ESI} \dagger$ for additional information), with Nafion or FAB membranes. The cell was constructed using a pair of thermostated diffusion cells (PermeGear). A flattened copper wire was used as the anode and tungsten or Pt wire (diameter $1 \mathrm{~mm}$, wound in a $3 \mathrm{~mm}$ spiral, effective electrode area of $1.7 \mathrm{~cm}^{2}$ ) as a cathode. Additionally, a tungsten cathode of a similar size was tested. The anode side halfcell was filled with $3.4 \mathrm{ml}$ of $0.5 \mathrm{M} \mathrm{H}_{2} \mathrm{SO}_{4}$ in $6 \mathrm{M} \mathrm{ACN}$ and the cathode side with an identical solution additionally containing $0.1 \mathrm{M} \mathrm{CuSO}_{4}$. The cells were thermostated to $50 \pm 2{ }^{\circ} \mathrm{C}$. An Autolab PGSTAT100 was used for testing of the batteries and for measuring the cell impedance. Charging-discharging experiments were performed with a Neware battery cycler (China) with the voltage limits of $1.1 \mathrm{~V}$ and $-0.1 \mathrm{~V}$ at $5 \mathrm{~mA}$ current and of $0.98 \mathrm{~V}$ and $0.2 \mathrm{~V}$ at $1 \mathrm{~mA}$ current. Afterwards the measured potentials were $i R$ corrected based on impedance spectroscopy measurements.

For preparation of the $\mathrm{Cu}(\mathrm{I})$ complex, $0.1 \mathrm{M} \mathrm{CuSO}_{4}$ in $6 \mathrm{M}$ acetonitrile (acidified to $\mathrm{pH} 2.5$ with sulphuric acid) was reacted with excess $\mathrm{Cu}$ powder in a reaction flask under nitrogen atmosphere. The set-up was purged with ACN saturated nitrogen for at least 30 minutes, and the temperature was elevated to $55{ }^{\circ} \mathrm{C}$ under reflux. The blue solution became colourless after two hours as the comproportionation reaction was completed. A sample taken from the solution was heated to $100{ }^{\circ} \mathrm{C}$ and nitrogen was bubbled through the solution to evaporate the acetonitrile. The solution turned blue and copper powder was precipitated on the bottom of the vial. The powder was analysed with SEM and XRD.

\section{Results and discussion}

The electrochemical behaviour of $20 \mathrm{mM} \mathrm{CuSO}_{4}$ in $0.5 \mathrm{M} \mathrm{H}_{2} \mathrm{SO}_{4}$ and $6 \mathrm{M}$ acetonitrile at a $5 \mathrm{~mm}$ Pt disk was first investigated with rotating disk electrode voltammetry. Fig. 1A shows a quasireversible reduction wave of $\mathrm{Cu}^{2+}$ to $\mathrm{Cu}^{+}$at $0.5 \mathrm{~V}$ and reduction of $\mathrm{Cu}^{+}$to copper at $-0.18 \mathrm{~V}$. A copper stripping peak is evident on the reverse scan. The results show that the cell potential should vary between 0.61 and $0.4 \mathrm{~V}$ for a fully charged and discharged cell, respectively, as we can assume that the copper electrode is at $0 \mathrm{~V} v s$. the $\mathrm{Cu}$ reference and the potential of the $\mathrm{Cu}^{2+}$ electrode depends on the ratio of $\mathrm{Cu}^{2+}$ and $\mathrm{Cu}^{+}$ according to the Nernst equation.

The simple miniature redox flow battery described earlier ${ }^{16}$ was used to study the cycling behaviour of the electrochemical system. The voltammetry for $100 \mathrm{mM} \mathrm{CuSO}_{4}$ in $0.5 \mathrm{M} \mathrm{H}_{2} \mathrm{SO}_{4}$ and $6 \mathrm{M}$ acetonitrile in the cell before cycling is shown in Fig. 1B. The convection in the cell was insufficient to achieve steady state conditions, and the cell potential is slightly higher than expected from RDE measurements, probably due to the presence of oxygen in the cell. Also, the cell was not fully charged, probably for the same reason. Comparison of the cycling behaviour of the cells with FAB or Nafion membranes and tungsten wire as a cathode and FAB membrane with $\mathrm{Pt}$ cathode was also performed. When FAB membranes were used, coulombic efficiencies close to $100 \%$ were achieved with both
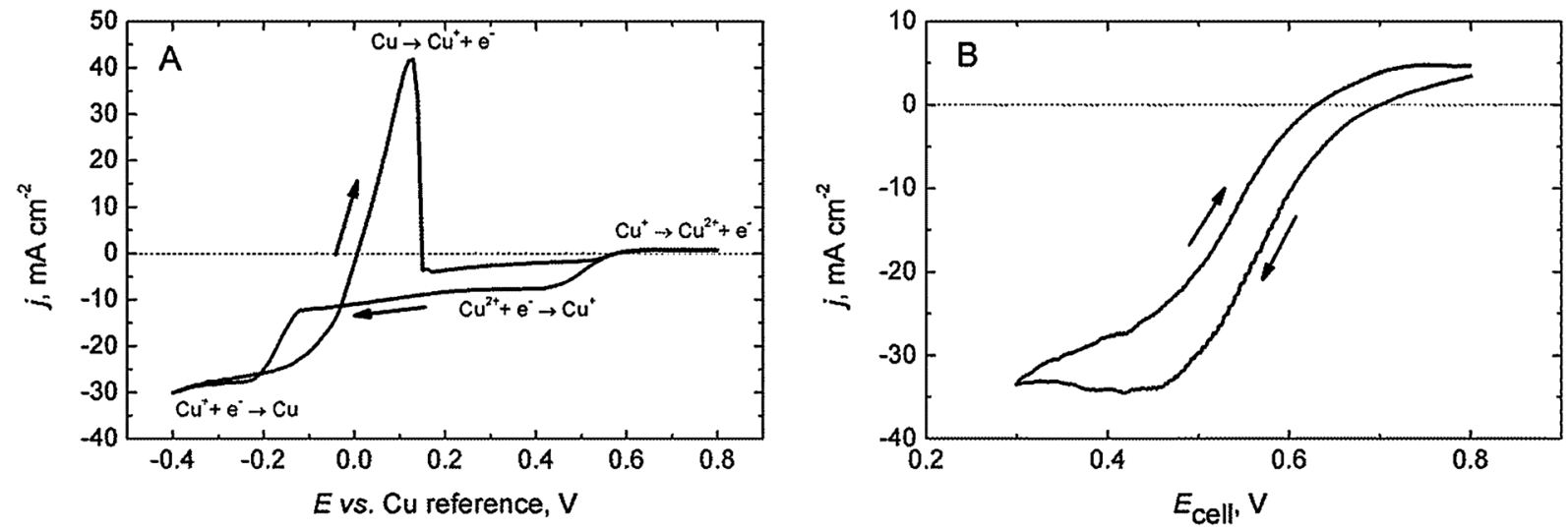

Fig. 1 (A) The cyclic voltammetry of $20 \mathrm{mM} \mathrm{CuSO}_{4}$ in $500 \mathrm{mM} \mathrm{H}_{2} \mathrm{SO}_{4}$ and $6 \mathrm{M}$ acetonitrile on $5 \mathrm{~mm}$ Pt disk electrode, $T=50{ }^{\circ} \mathrm{C}$, RDE speed $1000 \mathrm{rpm}$ and scan rate $50 \mathrm{mV} \mathrm{s}^{-1}$. (B) The $i R$ compensated cyclic voltammetry of $100 \mathrm{mM} \mathrm{CuSO}_{4}$ in $500 \mathrm{mM} \mathrm{H}_{2} \mathrm{SO}_{4}$ and $6 \mathrm{M}$ acetonitrile in the miniature redox flow battery with Pt cathode and FAB membrane, $50{ }^{\circ} \mathrm{C}, 500 \mathrm{rpm}$ and scan rate $50 \mathrm{mV} \mathrm{s}^{-1}$. 
tungsten and Pt electrodes. At higher currents the coulombic efficiency shows slight variation due to very sharp changes in the cell potential at the end of charge or discharge cycles, but the average value is close to $100 \%$. The measurements with Nafion showed that copper cations will transfer through the membrane, leading to much lower coulombic and energy efficiencies (85\% and 55-40\% respectively, at $7.86 \mathrm{~mA} \mathrm{~cm}^{-2}$ ) and lower cell voltages, and hence an anion exchange membrane is preferable. The conductivities of anion exchange membranes are significantly lower compared to cation exchange membranes, so the ohmic losses become excessive at high current densities. However, anion exchange membranes give an indication of system performance when minimal crossover of electroactive species occurs, e.g. with cation exchange membranes and high enough flow rates. Tungsten dissolved slowly during cycling, forming a yellow precipitate in the catholyte chamber, and hence it is unsuitable as an electrode material.

Fig. 2 shows the $i R$ corrected behaviour of the RFB with a Pt electrode and FAB membrane at different galvanostatic currents (for calculation of these parameters, see ESI $\dagger$ ). With a $7.86 \mathrm{~mA} \mathrm{~cm}^{-2}$ current density the open circuit cell potential was $0.56 \mathrm{~V}$ and $0.48 \mathrm{~V}$ after charging and discharging respectively. The open circuit potential gives an indication of the state of charge. The capacity and energy efficiency were stable during cycling, but only $37 \%$ of the theoretical capacity of $9.11 \mathrm{~mA} \mathrm{~h}$ based on $\mathrm{Cu}^{2+}$ content was utilized (see ESI $\dagger$ for calculation of the theoretical capacity) 2.25 times higher capacities (84\% of the theoretical capacity) were achieved with $1.57 \mathrm{~mA} \mathrm{~cm} \mathrm{~cm}^{-2}$ current density, with cell potentials of $0.62 \mathrm{~V}$ and $0.40 \mathrm{~V}$ after charging and discharging, respectively. These potentials correspond well with the cell potentials expected based on RDE measurements.

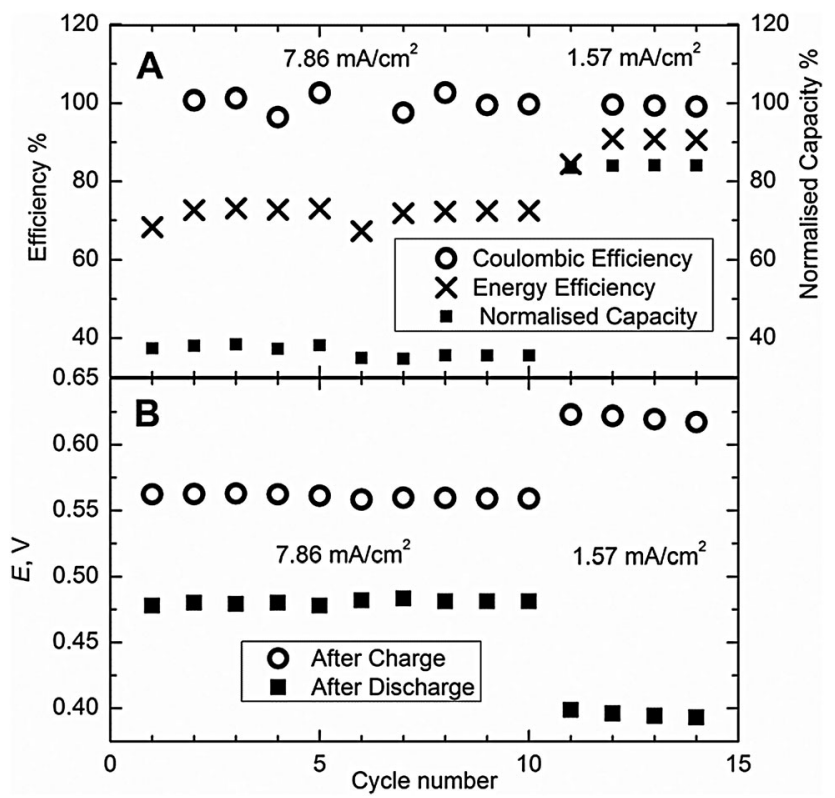

Fig. 2 iR-Corrected cycling data, (A) capacity and efficiencies, and (B) open circuit cell potentials after charge and discharge at different charge and discharge currents.
The battery can be almost fully charged or discharged with a current density of $1.57 \mathrm{~mA} \mathrm{~cm}^{-2}$, but $7.86 \mathrm{~mA} \mathrm{~cm}^{-2}$ allows the utilization of only $40 \%$ of the cell capacity. Good energy efficiencies of $73 \%$ (average of 8 cycles at $7.86 \mathrm{~mA} \mathrm{~cm}^{-2}$ ) and $90 \%$ (average of 3 cycles at $1.6 \mathrm{~mA} \mathrm{~cm}^{-2}$ ) were achieved.

The energy efficienciency of the battery compares well with the energy efficiencies reported for zinc-bromide (80\%), Fe-Cr (66-72\%), all-vanadium (72\%), and lead-acid batteries $(70-75 \%) .{ }^{17}$ The current densities achieved with the cell are too low for practical applications (although they compare well with the current densities reported for non-aqueous redox flow batteries ${ }^{16,18}$ ), but could be improved by increasing the $\mathrm{Cu}^{2+}$ concentration. However, this is not possible with $\mathrm{CuSO}_{4}$ as the solubility limit in the presence of sufficient acetonitrile is only $0.55 \mathrm{M}$ and relatively independent of temperature (see $\mathrm{ESI} \dagger$ ). Hence different copper salts have to be considered to improve the battery performance.

The long term stability of the freshly assembled cell was tested for 50 cycles at $7.86 \mathrm{~mA} \mathrm{~cm} \mathrm{~cm}^{-2}$ current density. Energy efficiencies were $76 \pm 2 \%$. Cell capacity decreased gradually, by $10 \%$ after 30 cycles and $20 \%$ after 50 cycles. This problem arises from incomplete charging, as the cell voltage after charging decreases from $0.620 \mathrm{~V}$ to $0.57 \mathrm{~V}$ during 50 cycles. $\mathrm{Cu}^{+}$also tended to replate onto the copper wire as loosely adherent nodules easily falling to the bottom of the cell. This problem may be solved by addition of additives used in industrial electroplating. Another source of capacity losses is the gradual evaporation of acetonitrile. The reported current densities are insufficient for commercial applications, but significant improvement should be possible by increased copper concentrations and optimisation of the cell design to enhance mass transfer.

Ohmic losses in the cell were $31 \Omega$ before cycling and $29 \Omega$ after cycling. This arises mostly from poor electrolyte conductivity, as the contribution of the membrane was only $0.5 \Omega$. These $i R$ losses can be minimized by optimizing the battery geometry. The other cell voltage losses arise from activation overpotentials and concentration polarisation. Activation overpotential can be roughly estimated from the change in the cell voltage when the cell is turned on after the rest period at the open circuit voltage. At $7.86 \mathrm{~mA} \mathrm{~cm} \mathrm{~cm}^{-2}$ the activation overpotential was $c a$. 44-45 $\mathrm{mV}$ for both charge and discharge. At $1.57 \mathrm{~mA} \mathrm{~cm}^{-2}$ this overpotential decreased to $25-29 \mathrm{mV}$, as can be expected based on Butler-Volmer kinetics. Overall the energy losses due to activation overpotential and concentration polarisation limit the energy efficiency to $73 \%$ at $7.86 \mathrm{~mA} \mathrm{~cm}^{-2}$ and $90 \%$ at $1.57 \mathrm{~mA} \mathrm{~cm}$ c $^{-2}$. The cell potential is low, but increases with acetonitrile content. ${ }^{19}$ In the absence of water the cell potential is expected to be around $1.35 \mathrm{~V} .^{9,19}$

When the comproportionation of $\mathrm{Cu}^{2+}$ and $\mathrm{Cu}$ was performed in a reaction flask, the blue solution became colourless after two hours, as shown in Fig. 3A. When acetonitrile was removed by heating the solution to $100{ }^{\circ} \mathrm{C}$ under nitrogen purge, copper powder precipitated and the solution turned blue.

SEM and XRD analysis confirmed that the copper powder formed consisted of $c a .100 \mu \mathrm{m}$ agglomerates with a small 


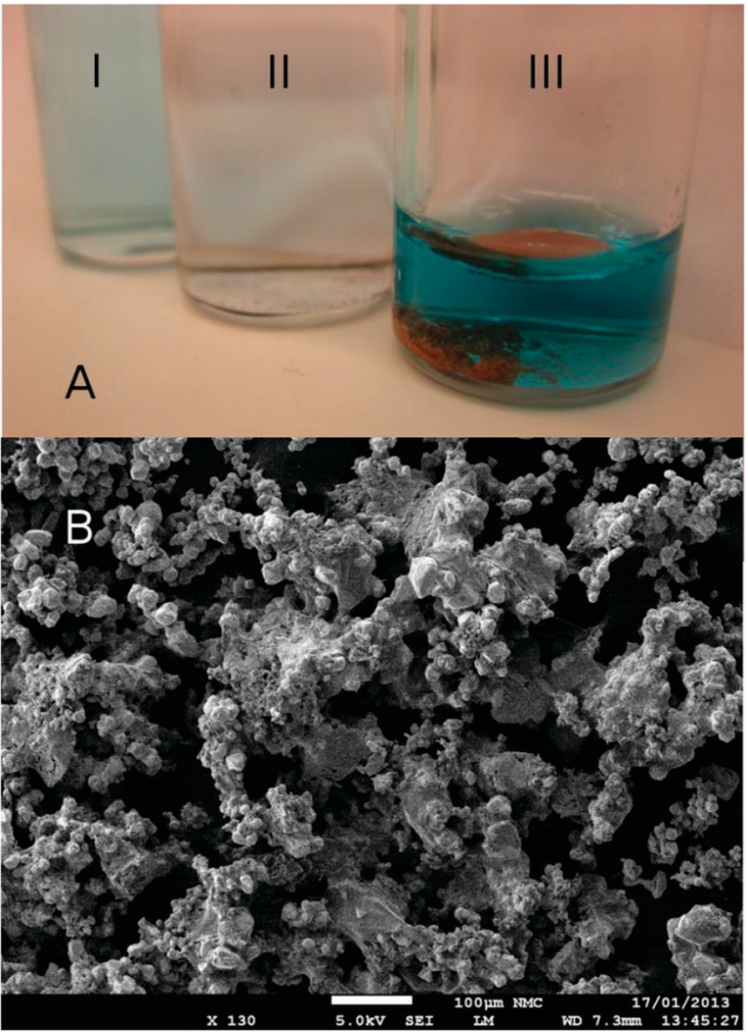

Fig. 3 (A) $0.1 \mathrm{M} \mathrm{CuSO}_{4}$ in $6 \mathrm{M}$ acetonitrile (I), [Cu(ACN) $)_{2} \mathrm{SO}_{4}$ solution prepared by comproportionation (II) and the copper powder and $\mathrm{CuSO}_{4}$ recovered after evaporation of acetonitrile (III). (B) SEM image of formed copper powder.

signal for $\mathrm{CuO}$ measureable. Acetonitrile could be then be collected by condensation from the gas phase, as described by Parker et al. ${ }^{8}$ Fig. 3 shows that copper powder and $\mathrm{CuSO}_{4}$ solution can be easily recovered by thermal regeneration. Recovered copper should be usable as the electrode of the battery, by circulating a copper suspension as the anolyte of the flow battery and $\mathrm{CuSO}_{4}$ as the catholyte. Other options include heat sintering the powder to form electrodes. If the solution was not stirred during evaporation of acetonitrile a thin copper film formed on the surface of the solution.

Preliminary studies with copper suspension in an anolyte of a conventional flow cell have shown that the concept works, although clogging of pipes and flow channels as well as the sedimentation of powder into the storage container can be a serious problem. Further work to demonstrate a working flow battery coupled with thermal regeneration is in progress.

\section{Conclusions}

We have shown an all-copper battery based on copper complexation with acetonitrile. The system can be used as a regular RFB to store energy with good efficiency, when surplus electricity is available. Alternatively, the battery can be charged by low grade heat. A fully optimized method to convert such heat into electricity could be revolutionary, as these sources are abundant.
This communication outlines the operating principles of the thermally regenerative redox flow battery. The next step is to couple the redox flow battery and thermal regeneration process. This topic is currently under investigation in our laboratory. The main technical problems to be solved before realization of the thermally regenerative battery are: circulation of a solid copper suspension without precipitation and blockage of the system, achievement of good electronic contact between particles and current collector and the efficient collection of distilled acetonitrile.

For a fully working system, the aim is to have a suspension of copper in the anolyte side circulated around with a pump. After discharge both anolyte and catholyte are combined for regeneration, which gives solid copper particles and a solution of $\mathrm{CuSO}_{4}$. Copper is filtered off, and a solution of $\mathrm{CuSO}_{4}$ is further concentrated to minimize the water content. The distilled acetonitrile is collected and added into the $\mathrm{CuSO}_{4}$ solution. If the water content is sufficiently low, almost all of the $\mathrm{CuSO}_{4}$ will precipitate, but sulphuric acid will stay in the solution. Now half of the collected acetonitrile is added to the solid copper, and both solutions are diluted with water to recover the original solutions, which can be circulated in the battery again.

\section{Acknowledgements}

Financial support from Aalto University is gratefully acknowledged.

\section{Notes and references}

1 I. Johnson and W. T. Choate, Waste Heat Recovery: Technology and Opportunities in U.S. Industry, BCS Incorporated, 2008.

2 W. S. Duff and D. A. Hodgson, Sol. Energy, 2005, 79, 25-32.

3 M. T. Balta, I. Dincer and A. Hepbasli, Int. J. Energy Res., 2010, 34, 757-775.

4 R. O. Loutfy, A. P. Brown and N.-P. Yao, US Pat., 4,410,606, 1983.

5 H. H. Morgan, J. Chem. Soc. Trans., 1923, 123, 2901-2907.

6 B. J. Hathaway, D. G. Holah and A. E. Underhill, J. Chem. Soc., 1962, 2444-2448.

7 S. Schaltin, N. R. Brooks, K. Binnemans and J. Fransaer, J. Electrochem. Soc., 2011, 158, D21-D27.

8 A. J. Parker, D. M. Muir, Y. C. Smart and J. Avraamides, Hydrometallurgy, 1981, 7, 213-233.

9 B. Kratochvil and K. R. Betty, J. Electrochem. Soc., 1974, 121, 851-854.

10 P. Leung, X. Li, C. Ponce de Leon, L. Berlouis, C. T. J. Low and F. C. Walsh, RSC Adv., 2012, 2, 10125-10156.

11 W. Wang, Q. Luo, B. Li, X. Wei, L. Li and Z. Yang, Adv. Funct. Mater., 2013, 23, 970-986.

12 H. L. Chum and R. A. Osteryoung, Review of Thermally Regenerative Electrochemical Systems, Solar Energy Research Institute, 1980.

13 H. L. Chum and R. A. Osteryoung, Review of Thermally Regenerative Electrochemical Systems, Solar Energy Research Institute, 1981. 
14 P. Kanninen, M. Borghei, V. Ruiz, E. I. Kauppinen and T. Kallio, Int. J. Hydrogen Energy, 2012, 37, 19082-19091.

15 D. Lloyd, T. Vainikka, S. Schmachtel, L. Murtomäki and K. Kontturi, Electrochim. Acta, 2012, 69, 139-145.

16 D. Lloyd, T. Vainikka and K. Kontturi, Electrochim. Acta, 2013, 100, 18-23.
17 C. Ponce de León, A. Frías-Ferrer, J. González-García, D. A. Szánto and F. C. Walsh, J. Power Sources, 2006, 160, 716-732.

18 S.-H. Shin, S.-H. Yun and S.-H. Moon, RSC Adv., 2013, 3, 9095-9116.

19 B. G. Cox, A. J. Parker and W. E. Waghorne, J. Phys. Chem., 1974, 78, 1731-1740. 